account therefore was directed to an Italian-speaking audience fully familiar with the Donation of Constantine and with a history of Catholic crusading against Muslims in the eastern Mediterranean. In those turbulent times, so grandiose a claim to immunities and to status as a holy land did not carry the day either in Renaissance Italy or on Cyprus. As the medieval popes had already discovered, high claims to imperial terrestrial sovereignty without the protection of a cooperative earthly power often proved difficult to sustain. Yet, like the rediscovery of St Barnabas's relics at a more opportune time of need, Bustron's claim to imperial privileges would be recovered in later modern historical contexts where it would bear much more fruit. Ironically, this would all take place under the auspices of two new imperial authorities: the Ottoman and British governments.

Jnl of Ecclesiastical History, Vol. 66, No. 2, April 2015. C Cambridge University Press 2015 doi:10.1017/Soo22046915000019

\title{
The Eusebius Essay Prize
}

The Eusebius Essay Prize, of $£_{5}$ oo, is offered annually for the best essay submitted on a subject connected with any aspect of early Christian history, broadly understood as including the first seven centuries AD/ CE. Scholars in any relevant discipline (theology, classics, late antique studies, Middle Eastern Studies etc.), whether established in their field or graduate students, are encouraged to enter the competition. Submissions from younger scholars are particularly welcomed. The essay should not exceed 8,ooo words, including footnotes, and for 2015 should be submitted by 30 September. A judgement will be made at the end of November (the editors reserve the right not to award the prize if no essay of significant quality is submitted). The essay of the successful candidate will be published in the Journal, probably in the number appearing in July 2016. Other submissions entered into the competition may also be recommended for publication. All essays should be sent as two hard copies, prepared to journal style, to Mrs Anne Waites, Journal of Ecclesiastical History, Robinson College, Cambridge $\mathrm{CB}_{3}$ 9AN. 